Милош М. КОВАЧЕВИЋ

Филолошки факултет Београд

Филолошко-уметнички факултет Крагујевац
Оригинални научни рад

Примљен: 26. 11. 2018.

Прихваћен: 14. 02. 2019.

\title{
СТАТУС АТРИБУТИВА МЕЂУ ОДРЕДБАМА У СЛОВЕНСКИМ ЈЕЗИЦИМА**
}

\begin{abstract}
У раду се анализирају граматичка и научна тумачења именичких синтагми које у свом саставу имају синтаксичко-семантичке јединице које само србистичка литература назива атрибутивом (нпр.: пас трагач, професор Петровић; град Београд, новине „Политика”). Готово све друге филологије српски атрибутив сматрају апозицијом. У раду се доказује да је научно неодрживо тумачење по коме је атрибут(ив) шири појам који одређује ужи као „неодређен” појам, па чак кад је ужи појам и властито име, што најчешће и јесте. Показује се да је такво тумачење сагласно само апозицијском одређењу ових јединица. Неапозицијско, атрибутивно тумачење датих синтаксичких јединица критеријално је могуће само ако се за синтагматски надређену одреди именица ширега појма, коју онда као атрибут(ив) детерминише именица ужега појма.

Кључне ријечи: атрибут, апозиција, атрибутив, надређени члан синтагме, одређени појам, шири појам, ужи појам.
\end{abstract}

Нема ниједне граматике било кога словенског (или несловенског) језика, нити иједног рјечника лингвистичких термина у коме се као одредбе супстантивних ријечи не наводе атрибут и апозиција. Диференцијација између тих двију одредбених присупстантивних категорија није, међутим, критеријално јасна. Тој критеријалној нејасности доприноси прије свега категорија коју српске граматике именују атрибутивом, а која се у синтаксама различитих језика, па чак и синтаксама истога језика (нпр. дојучерашњег јединственог српскохрватског, данас именом раздвојеног на тобож више стандардних језика) - час сматра поткатегоријом апозиције, час поткатегоријом атрибута. А колико је у тој поткатегорији тешко раздвојиво атрибутско од апозитивног, можда је најбољи, иако посредни, показатељ термин „апозиција-атрибут” (приложение-атрибут) (Станковић 1986: 45), односно „атрибут-апозиција”

*mkovacevic31@gmail.com

** Рад је настао у оквиру пројекта 178014: Динамика структура савременог српског језика, који финансира Министарство просвете, науке и технолошког развоја Републике Србије. 
(определение-приложение) (Симеон 1969: 128), којим се неријетко, прије свега у русистици, означавала категорија „конгруиране именице у одредбеној функцији” (Станковић 1986: 45).

Ова синтаксичка конструкција, с особинама што је стављају на прелаз између атрибута и апозиције, ријетко гдје, мимо актуелне србистике, има и своје терминолошко одређење. Она се у готово свим словенским (као и несловенским) филологијама, изузме ли се србистика, најчешће сматра подтипом апозиције, с тим да се при њеној интерпретацији по правилу указује и на специфичне карактеристике које је повезују с атрибутом.

Значајно је, међутим, поменути да је, без обзира на то да ли је ова поткатегорија сматрана апозицијском или атрибутивном - и у једној и у другој интерпретацији наглашавана дилема о синтаксичком статусу њених компонената, тј. дилема која је од именица управни а која зависни члан супстантивне, атрибутске или апозитивне, синтагме (нпр. у синтагми град Београд, или професор Петровић, или планина Озрен и сл.).

Но, прије разматрања тог проблема, потребно је указати на покушаје специфичног терминолошког одређења ове синтаксичке конструкције. Истраживања српске граматичке терминологије 19. вијека показала су да је још Ђура Даничић „под спојним додаџима или атрибутима подразумевао конгруентне атрибуте и атрибутиве", исто као и Ј. Бошковић, а сљедствено њима и С. Новаковић и Љуба Стојановић (Мацановић 2018: 322-323).

Терминолошку диференцијацију конкурентних именичких и придјевских (конгруентних) атрибута дао је, тек у другој половини XX вијека, М. Стевановић. Он сматра да „именице пак које такође стоје уз друге именице и врше службу њихова одређивања, али не означавају исти већ шири појам, појам врсте или рода коме главни појам припада, затим појам, такође шири, титуле или звања, односно занимања и особине које главни појам има, као у примерима извор вода, село Бистрица, река Зета, грађанин племић, иар Стјепан, жгоља чобанин и сл. - по служби својој нису ништа друго већ атрибути”; друкчије речено, да ту „именице нису употребљене у служби апозиције већ у служби атрибута" (Стевановић 1979: 60-61). Зато је - вели Стевановић - оправдано „и именице уз друге именице у служби придева сврстати међу атрибутске одредбе. Питање је само којим их именом ту звати. Да ли их једноставно звати атрибутским апозищијама, којим смо их именом досад у својим предавањима звали, и како их и други неки граматичари називају․․ Овај термин ипак није срећно нађен за именице у служби атрибута зато што их ставља у синтаксичку категорију којој не припадају, ставља их ипак у апозиције, а оне то, како смо видели, нису. Нама се чини да би за њих, аналогно термину апозитив (за придевске речи у апозитивној служби), боље одговарао назив атрибутив (категорија именица у служби атрибута). [...]

\footnotetext{
${ }^{1}$ Који је, ако је судити по литератури (в.: Стевановић 1958: 32; Миновић 1968: 88), први употријебио Ј. Вуковић.
} 
А могле би се ове одредбе звати и именички атрибути" (Стевановић 1979: $63)^{2}$.

Термина атрибутив нема ни у једној граматици било ког словенског или несловенског језика, нити у било ком познатијем лингвистичком рјечнику (нпр. код Ахманове 1966, Симеона 1969, Кристала 1988), нити у било којој граматици словенских и несловенских језика, осим у граматикама српског језика. У готово свим актуелним граматикама српскога језика, па и у енциклопедијским рјечницима које су приредили србисти - употребљава се термин атрибутив, и тумачи сагласно учењу М. Стевановића. (уп.: Пецо/Станојчић ред. 1972: 36; Станојчић/Поповић 1992: 255; Станојчић 2010: 314-315; Пипер/Клајн 2013: 306; Симић 1999: 235-240).

У нормативној граматици П. Пипера и И. Клајна (2013) једном садржајно проблематичном реченицом указано је на међуоднос атрибутива и апозиције: „Атрибутив треба разликовати од апозиције, мада су у старијим граматикама и такви примери називани апозицијама” (Пипер/Клајн 2013: 306). Посматран из перспективе српских граматика садржај главне клаузе дате реченице потпуно је тачан - јер се заиста од Новаковићеве до најновијих граматика атрибутив увијек разматрао као врста атрибута, а не апозиције. Други дио Пипер-Клајнове реченице изражен концесивном клаузом («мада су у старијим граматикама и такви примери називани апозицијама») двоструко је, међутим, нетачан чак и кад се односи само на српске граматике. Наиме, ни у једној старијој српској граматици синтаксичке конструкције које се данас именују атрибутивима нису сматране апозицијама него атрибутима (в.: Мацановић 2018: 322-324). Али зато јесу у једној од НАЈНОВИЈИХ, чији је аутор управо један од коаутора наведене нормативне граматике, па сљедствено и наведене реченице - И. Клајн (2005), који каже ,да су у апозииији две именице стављене једна уз другу тако да једна поближе означава и одређује другу”, и да се „најчешће апозиција налази испред властитих имена: госnођа Лукић, професор Кашанин, краљь Петар, чика Јова, баба Милииа, ресторан 'Пролеће', језеро Балатон, река Мисисипи и сл. Ређе апозиција долази ПОСЛЕ имена и тада се одваја запетом: Стојан Матић, новинар”, с тим да су „посебна врста апозиције тзв. атрибутске апозиције или атрибутиви, у којима друга заједничка именица сужава значење прве: камен темељац, звезда падалица, сузе радоснице (= сузе од радости) и сл.” (Клајн 2005: 233-234).

То код Срба издвојено (ексклузивно) мишљење И. Клајна о атрибутивним конструкцијама као апозицијским јесте унисоно, општеприхваћено мишљење свих хрватских граматичара. Хрватски граматичари сматрају да су сви типови синтаксичких конструкција који се у србистици сматрају атрибути(ви)ма - праве апозиције: в. нпр. Маретић (1963: 483-484), Бра-

\footnotetext{
${ }^{2}$ Прво издање Стевановићевог Савременог српскохрватског језика II: Синтакса изашло је 1969. године, али у наведеној књизи Стевановић није први пут употријебио термин атрибутив, него у раду објављеном 1958. године (Стевановић 1958: 23-34), који је готово у цјелини, без иједне суштинске измјене, укључен у наведену Стевановићеву универзитетску синтаксу. Иначе, тај се термин, без позивања на Стевановића, прије Стевановићевог универзитетског уџбеника, сусреће још само у раду М. Ајановића о апозицији (1968: 71, 80), који каже да га је «некад чуо или негдје нашао» (Ајановић 1968: 71).
} 
бец/Храсте/Живковић (1968: 195), Бабић (1963: 13), Барић и др. (1979: 423-424; 432), Катичић (1986: 458-452), Силић/Прањковић (2005: 313-314). Апозицијом овакве конструкције сматрају и граматичари већине других словенских језика ${ }^{3}$, као нпр. у чешком Хавранек, Једличка (1963: 364-365), у лужичкосрпском Шевц-Шустер (1976: 72-73); у бугарском Бојаџијев и др. (1999: 522), у руском Валгина (2000: 119-121), у бјелоруском Роговцов (2001: 52-55), и др.

Без обзира на то да ли такве примјере сматрају атрибут(ив)има или апозицијама, граматичари често износе дилему у погледу хијерархијског синтаксичког односа именица у саставу такве синтагме. То питање није једнообразно ријешено у словенским језицима, па се сусрећу обрнута рјешења чак и код различитих аутора унутар истога језика. ${ }^{4}$

У србистици и/или сербокроатистици готово увијек се именица са ширим опсегом проглашава зависном у односу на именицу ужега опсега, без обзира да ли се та именица сматра атрибутом или апозицијом (уп. нпр.: Маретић 1963: 483. и Стевановић 1979: 62). „Инаугуративно” Стевановићево тумачење да у атрибутивним синтагмама шири појам одређује ужи прихваћено је у готово свим новијим српским граматикама, рјечницима и научним радовима.

Мишљење да у именичким синтагмама састављеним од двију именица она која означава шири појам одређује ону која означава ужи - у несрбистичкој, најчешће русистичкој (в. Станковић 1986) литератури оспоравано је прије свега структурним морфосинтаксичким критеријумима, од којих су два најбитнија: а) предикат реченице конгруира са номинативном именицом ширег а не ужег семантичког опсега (нпр.: Град Суботица је пријатан за живот), и б) атрибутивна синтагма у везу са другим члановима реченице увијек ступа преко именице ширега, а не преко именице ужега значењског опсега (нпр.: Боравили смо на реци Рзав) (Бабајцева 2015: 276).

Иако су једино навођени као показатељи неутемељености мишљења да је ужи појам управни члан оваквих именичко-атрибутивних синтагми, дати структурни критеријуми (конгруенција с предикатом синтагматски појмовно ширег члана и укључење дате синтагме преко тог члана у реченичну структуру) не само да нису једини, него нису ни најзначајнији показатељи да је именица ширега, а не ужега семантичког опсега управни члан синтагме.

Мимо двају наведених структурних, још неколика прије свега логичко-семантичка критеријума недвосмислено оповргавају тумачење да је ужи појам „неодређен” па се његово одређење у синтагми врши навођењем ширег појма као атрибутива.

За разјашњење синтаксичко-семантичког међуодноса чланова синтагме састављене од двију именица од којих прва именује шири а друга ужи појам

\footnotetext{
${ }^{3}$ Изузетак су синтаксичари македонског и словеначког језика, који међу примјерима „именског атрибута" наводе и оне с атрибутивом (Минова Ђуркова 2000; Топоришич 2004).

${ }^{4}$ Најбоља потврда томе јесу супротна рјешења у русистици, чији приказ даје Станковић (1986: 45-47), а то је карактеристика и актуелних граматика рускога језика, уп. нпр. супротна рјешења која дају Валгина (2000: 119-121) и Бабајцева (2015: 205-206).
} 
- врло су значајни, заправо незаобилазни, иако у досадашњим анализама неукључивани, сљедећи критеријуми:

1) логичко-семантички принцип детерминације

2) принцип хипонимске инклузије

3) семантички принцип рестрикције и нерестрикције

4) могућност употребе језичких верификатора субординираности (типа: звани, по имену, са/под именом, са/под називом/насловом и сл.).

Детерминација или одређивање у логици значи „поступак (супротан апстракцији) којим се сужава опсег одређеног појма додавањем ознака, а проширује његов садржај. Од ширег се добија ужи појам. Детерминирати значи поближе одредити неки појам додавањем нових ознака" (Филиповић (ред.) 1989: 67). Из тога слиједи да је детерминирани појам увијек конкретнији од појма који се детерминише. Зато одређење или детерминација у логици значи и „придодавање неког обележја појму у суду (нпр. троугао је једнакостранични), којим из неког општег појма настаје мање општи појам” (Регенбоген/Мајер (ред.) 2004: 401). Друкчије речено, детерминацијом општи појам сводимо на мање апстрактан, конкретан или индивидуалан. Зато је потпуно несагласна логичким принципима детерминације тврдња према којој шири (општији) појам може детерминисати ужи (конкретнији) појам. Логичко тумачење детерминације једнозначно упућује на то да у синтагми село Бистрицุа, или птицุа ластавица - село и птиц̧а као шири (општији) појмови никако не могу оређивати појмове Бистрица и ластавица као уже (конкретније), него управо обрнуто: шире појмове село и птица одређују ужи појмови Бистрица и ластавица. Пошто је основна комуникативна улога атрибута управо детерминација, готово да силогистички проистиче да у наведеним синтагмама само Бистрица и ластавища као ужи појмови могу бити атрибути или атрибутиви именицама село и птица, а никако обрнуто.

А да су село и птищза шири појмови од Бистрищза и ластавищуа, недвосмислено показује и принцип инклузије хиперонимског типа. „Хипонимија је релација инклузије и представља један од фундаменталних лексичких односа у језику. [...] Однос инклузије се заснива на вези између надређеног (суперординираног) појма и подређених (субординираних) појмова. На исти начин се анализира и однос између лексема које означавају такве појмове. Лексема иявет је надређена (суперординирана) лексемама ружа, лала, каранфил, љубичица итд. Хипонимија је однос између суперординиране и субординираних лексема" (Драгићевић 2007: 290). Инклузивни хипонимски однос подразумијева начело: ХИПОНИМ ЈЕ ДИО (ЈЕДАН ОД) ХИПЕРОНИМА. А на хипонимском односу увијек се заснивају атрибутивне синтагме у којима именице одражавају однос врсте (као хипонима) и рода (као хиперонима), или пак однос рода или врсте (као хиперонима) и индивидуализованог појма, нпр. било ког властитог имена (као хипонима). Врста је логички ужа од рода, а индивидуални појам је ужи од било ког неиндивидуализованог (врсног) појма. Зато индивидуализовани појам изражен властитом именицом 
представља најодређенији појам; он не може бити неодређен е да би тражио одређење другим појмом, јер другог ужег појма од њега и нема, а логички се искључује могућност да шири појам детерминише ужи. Зато је логично да „хипоними именују свој садржај директно, док је код хиперонима та функција остварена посредством хипонима" (Симић 1999: 132). Хијерархијска структура свих биноминалних синтагми са односом ширег и ужег појма јесте хипонимијска: синтагматски надређен је шири појам у функцији хиперонима, а подређен (субординиран) ужи појам као хипоним. Дато правило потврду налази у свим синтагмама у којима се шири појам изражава препозитивном апелативном именицом а ужи постпозитивном властитом или апелативном именицом, као нпр.: држава Србија = Србија је држава / једна од држава; град Београд = Београд је град / један од градова; глумаи Том Круз = Том Круз је глумаи / један од глумача; планина Рудник = Рудник је планина / једна од планина; краљ Милан = Милан је краљь / један од краљева, великан Тесла = Тесла је великан / један од великана; тетка Милена = Милена је тетка / једна од тетака; манастир Грачаница = Грачаница је манастир / један од манастира; хотел „Москва” = „Москва” је хотел / један од хотела; новине „Политика" = „Политика” су новине / једне од новина; птиияа ластавица = ластавица је птица / једна од птица; ивијет каранфил = каранфил је ивијет / једна од врста извиећа, мјесеи мај = мај је мјесеи / један од мјесеци; број шест = иест је број / један од бројева; везник „док” = „док” је везник / један од везника и сл.

Да ужи појам има детерминативну улогу у односу на шири, недвосмислено показује и могућност употребе језичких верификатора субординираности испред именице ужега појма, на које као критеријум скреће пажњу Б. Станковић (1986: 57, 60), посебно у случајевима када именице у синтагми стоје у логичко-семантичком односу рода и врсте, или пак рода или врсте и властитог имена као ознаке „одређеног”, индивидуализованог појма. А ти верификатори јесу изрази којима се врши називна спецификација, или индивидуализација општега појма. Улогу верификатора зависности неродног или неврсног члана синтагме имају предлошко-падежни изрази (слични предлошким изразима): по имену / презимену / надимку; с именом / презименом / надимком, под /са називом, или глаголски придјев зван, при чему се израз под називом / са називом употребљава само испред неанимативних именица, а изрази који у саставу имају именицу презиме и надимак само испред анимативних именица, као нпр.: министар Петар Петровић $\rightarrow$ министар по имену Петар Петровић; мајка Јевросима $\rightarrow$ мајка по имену Јевросима; великан Вук Караџић $\rightarrow$ великан по имену Вук Карачић; мјесто Улог $\rightarrow$ мјесто по имену / звано Улог; овчица Аска $\rightarrow$ овчица по имену / звана Аска; планина Јелица $\rightarrow$ планина по имену / звана Јелица; птица врабац $\rightarrow$ птица по имену / с именом / звана врабаи; мјесеи март $\rightarrow$ мјесеи по имену март; господин Марковић $\rightarrow$ господин с презименом / под презименом Марковић, роман „Госпођица” $\rightarrow$ роман под/ са насловом „Госпођица”; сплав „Ембарго” $\rightarrow$ сплав под / са именом / називом „Ембарго” итд. 
Све атрибутивне синтагме које у свом саставу имају властиту именицу, а и готово све синтагме у којима између апелативних именица влада однос рода и врсте или индивидуализованог појма (као нпр. синтагме с именицом мјесеи у свом саставу) могу се трансформисати у синтагме с наведеним верификативним изразима субординираности.

Датим изразима врши се рестрикција ширег појма, његово свођење на јединачни, индивидуализовани појам изражен властитим именом. Рестриктивност је основна функција атрибута, били они придјевски или именички. „Будући да се атрибути дијеле на два типа с обзиром на учинак који поближе одређивање именске ријечи има на опсег референта те ријечи, разликују се и међу релативним реченицама истоимени типови: рестриктивни и нерестриктивни (апозитивни). За рестриктивни је карактеристично да сужава опсег референта именске ријечи, а за нерестриктивни да не утјече на опсег референта" (Кордић 1995: 25-26).

Именица која је у оквиру биноминалне синтагме супституентна и семантички еквивалентна са рестриктивном релативном реченицом - има детерминативну (одредбену) улогу, тј. статус зависног одредбеног атрибутског члана. Супституентност је тада недвосмислен показатељ да дата именица попут синонимне релативне рестриктивне клаузе сужава опсег референта именице уз коју стоји. У свим синтагмама састављеним од апелативне и властите именице - властита именица је безизузетно еквивалентна рестриктивној атрибутској клаузи, па је сама њихова замјена верификатор синонимности, као нпр.: ћелавко Мел Ферер $\rightarrow$ ћелавко који се зове Мел Ферер; посланик Црногорац $\rightarrow$ посланик који је Црногорац; општина Сурчин $\rightarrow$ општина која се зове Сурчин; брдо Стражевица $\rightarrow$ брдо које се зове Стражевица; село Придворииа $\rightarrow$ село које се зове Придворица; манастир Манасија $\rightarrow$ манастир који се зове Манасија; центар Сава $\rightarrow$ центар који се зове Сава; ријека Неретва $\rightarrow$ ријека која се зове Неретва; пекар Бата Булин $\rightarrow$ пекар који се зове Бата Булин; тенисер Новак Боковић $\rightarrow$ тенисер који се зове Новак Боковић; отац Анђелко $\rightarrow$ отац који се зове Анђелко; друг Пера $\rightarrow$ друг који се зове Пера; учитељ Власта $\rightarrow$ учитељ који се зове Власта; кнегиња Милица $\rightarrow$ кнегиња која се зове Милица; глумац Шон Пен $\rightarrow$ глумац који се зове Шон Пен; Немица Хелга $\rightarrow$ Немица која се зове Хелга; ураган Хектор $\rightarrow$ ураган који се зове Хектор; хотел „Србија” $\rightarrow$ хотел који се зове Србија; часопис „Нова Зора” $\rightarrow$ часопис који се зове „Нова Зора”; пјесма „Отаибина” $\rightarrow$ пјесма која се зове „Отаибина”; мјесец јун $\rightarrow$ мјесец који се зове јун; жена политичар $\rightarrow$ жена која је политичар; земља чланица $\rightarrow$ земаља која је чланица; метода Шијацу $\rightarrow$ метода која се зове Шијаиу; жене војници $\rightarrow$ жене које су војници; жена пилот $\rightarrow$ жена која је пилот, љекар специјалиста $\rightarrow$ љекар који је специјалиста; змија отровница $\rightarrow$ змија која је отровница / omровна; пси луталице $\rightarrow$ пси који су луталице / који лутају; коњ липицанер $\rightarrow$ коњ који је липицанер и сл.

Критеријум рестриктивности и критеријум хипонимијске инклузије укидају разлику коју србистички радови праве између типова атрибутива који се изражавају именицом која означава шири појам и именицом којом 
се изражава ужи појам. Наиме, у србистичким граматикама и научним радовима у атрибутивним синтагмама зависним чланом проглашавају се ријечи које значе шири појам, појам врсте или рода, појам титуле или звања, појам занимања и особине, а главним компонентама се проглашавају речи које значе ужи појам, конкретни назив припадника врсте или рода, име носиоца титуле, звања, занимања и особине. Из тога се унисоно ИЗУЗИМАЈУ случајеви именичких синтагми у којима је једна именица, и то по правилу друга, деадјективна изведеница, па ју је могуће замијенити мотивним придјевом, као нпр.: змија отровница - отровна змија, иљива ранка - рана шььива, јабука дивљака - дивља јабука, мајка старица - стара мајка, свијећа воштаницุa-воштана свијећа и сл. У тим синтагмама „другом именицом се сужава значење исказано првом именицом (као главном речи)" (Станојчић/Поповић 1992: 255, уп. и: Пецо/Станојчић (ред.) 1972: 36; Мршевић Радовић 1976: 227; Симић 1999: 237-238; Станојчић 2010: 315; Пипер/Клајн 2013: 307). Такође се неријетко истиче да су оваквим синтагмама с деадјективним именицама аналогне и синтагме с другим типовима изведених именица, мада у њима изведену именицу није могуће замијенити придјевом (нпр.: пас луталица, писии реалисти, ђащи пјешации и сл.).

Док је разлика између синтагме с деадјективном именицом и мотивног придјева незнатна, дотле је она чак инкомензурабилна код синтагми с деадјективном именицом и придјевом употријебљеним испред властитог имена. Литература ту разлику једноставно превиђа. Тако П. Пипер и И. Клајн у својој нормативној граматици тврде да су и уз властите именице придјев и деадјективна именица синоними. Јер, „да атрибутив одређује именицу као што то чини придевски конгруентни атрибут, показује постојање синонимичних парова синтагми са атрибутом и са атрибутивом, нпр. светаи Алимпије - Свети Алимпије, великан Тесла - велики Тесла, проклетник ХУ - проклети $X У^{\prime \prime}$ (Пипер/Клајн 2013: 306). А те синтагме нису синонимне. Док конгруентни атрибут уз властиту именицу логички мора имати апозитивну улогу, улогу апозитива, јер не може идентификовати већ властитом именицом идентификовани појам, дотле деадјективна именица употријебљена испред властитог имена постаје шири појам, добија статус синтагматски надређене именице којом се означава врста или класа под коју је по правилу инклузије властито име супсумирано, што се најочигледније потврђује и могућношћу замјене рестриктивном релативном реченицом, уп.: великан Тесла $\rightarrow$ Тесла је један од великана / $\rightarrow$ великан који се зове Тесла; светац Алимпије $\rightarrow$ Алимпије је један од светаца / $\rightarrow$ светац који се зове Алимпије; љепотан Момчило $\rightarrow$ Момчило је један од љепотана / $\rightarrow$ љепотан који се зове Момчило; богаташ Бил Гејтс $\rightarrow$ Бил Гејтс је један од богатама $/ \rightarrow$ богаташ који се зове Бил Гејтс; новајлија Милић $\rightarrow$ Милић је један од новајлија / новајлија који се презива Милић итд.

Из проведене анализе слиједи закључак који има статус правила: Ако се посматрају као атрибутске и/или атрибутивне синтагме, именичке синтагме састављене од именица ширега појма и именице ужега појма - с тим да шири појам у стилски немаркираним контекстима долази испред ужег - за 
надређени (управни) члан имају именииу ширега појма, док функиију атрибутива као зависног члана увијек има именица којом се означава ужи појам.

То правило, међутим, не оповргава интерпретацију датих синтагми као апозищијских. А апозиција се у србистици и/или сербокроатистици одређује као именица уз именицу у истом падежу, при чему је апозитивна именица увијек додатак већ одређеном појму, и представља његово друго име. Апозиција је, дакле, својеврсно реименовање већ одређеног појма, с циљем његовог накнадног појашњавања. Друкчије речено, „апозиција је додати, адлоцирани назив са функцијом продубљивања и истицања номинације. Исти садржај она именује из друге перспективе, мање значајне са комуникацијског гледишта, али често стилски релевантне" (Симић 1999: 223).

У свим именичким апозитивним синтагмама састављеним од двију именица од којих је једна властита, будући да је апозиција додатак већ одређеној именици - властита именица, без обзира на мјесто у реченици, нужно је надређена заједничкој именици, јер је властита именица, означавајући индивидуални појам, одређенија од заједничке. Друкчије речено, „властито име надређено је опћој именици с којом стоји у вези, неовисно о томе стоји ли испред опће именице или иза ње”, и то зато што „властито име именује одређено биће, предмет и појаву, тј. потпуно је одређено у односу на опћу именицу" (Властелић 2007: 6). То потврђује трансформација заједничке именице у релативну реченицу, која тада, будући да долази уз „одређен” појам, мора бити нерестриктивног типа, као нпр.: великан Тесла $\rightarrow$ Тесла, који је великан; опитина Сурчин $\rightarrow$ Сурчин, који је опитина; брдо Стражевица $\rightarrow$ Стражевица, која је брдо; село Придворица $\rightarrow$ Придворица, која је село; манастир Манасија $\rightarrow$ Манасија, која је манастир; ријека Неретва $\rightarrow$ Неретва, која је ријека; пекар Бата Булин $\rightarrow$ Бата Булин, који је пекар; тенисер Новак Ђоковић $\rightarrow$ Новак Ђоковић, који је тенисер; отац Анђелко $\rightarrow$ Анђелко, који је отаи; пријатељь Пера $\rightarrow$ Пера, који је пријатељь учитељь Власта $\rightarrow$ Власта, који је учитељ; кнегиња Милица $\rightarrow$ Милица, која је кнегиња; глумаи Шон Пен $\rightarrow$ Шон Пен, који је глумаи; ураган „Хектор” $\rightarrow$ „Хектор”, који је ураган; хотел „Србија” $\rightarrow$ „Србија”, која је хотел; часопис „Нова Зора” $\rightarrow$ „Нова Зора”, која је часопис итд.

Исти је случај и са апозитивним синтагмама састављеним од двију заједничких именица од којих једна означава шири а друга ужи појам. Именица за ужи појам нужно је „одређенија” од именице ширега појма, па она има статус надређене, што се недвосмислено потврђује трансформацијом именице за шири појам у нерестриктивну (апозитивну) релативну реченицу, као нпр.: птица ластавица $\rightarrow$ ластавица, која је птица; мјесец март $\rightarrow$ март, који је мјесец; жена политичар $\rightarrow$ политичар, који је жена; жене војници $\rightarrow$ војници, који су жене; љекар специјалиста $\rightarrow$ специјалиста, који је љекар; змија отровница $\rightarrow$ отровница, која је змија; $n c u$ луталице $\rightarrow$ луталице, који су пси и сл.

Најбитнија разлика између апозиције и атрибутива као именичког атрибута семантичке је природе: именицом се именује исти, већ одређен појам, док атрибут(ив) сужава семантички опсег недовољно одређеног именичког 
појма. А та се разлика лако провјерава употребом (не)рестриктивне релативне реченице намјесто атрибутива и апозиције: атрибутиву је увијек еквивалент рестриктивна релативна клауза, а апозицији - нерестриктивна релативна клауза. Тај је критеријум недјелотворан једино у случајевима када се објема именицама што чине именичку (атрибутивну или апозицијску) синтагму изражава појам истог семантичког опсега, па се тек у контексту може одредити који је од њих „одређен” или „одређенији”, као нпр.: мушкарии насилници, инжеюери теоретичари, господар визионар, медицинар професионалаи, бомбаши самоубице, господин директор, син тинејцер, колеге музичари, дјечак биџиклиста, швалер криминалаи, жена пилот, жена академик, отаи председник, дечко спортиста, госпођа министарка, полицајаи херој, студенткиња дилерка, свједок сарадник и сл.

Апозиција је самосвојан спој именица и на семантичком и на синтаксичком плану, најприје по томе што именице у апозитивном односу „имају истоветну референцију и исту синтаксичку функцију” (Кристал 1988: 26). Друкчије речено, „чланови апозицијског односа су таутологија у значењском (семантичком смислу), а у синтаксичком смислу (по функцији) та два члана представљају функционалну синтагму [тј. независну, напоредну - М. К.], јер оба та члана, сваки за себе, имају исту функцију према трећем члану у реченици (Стевовић 1960: 32). А да је то тако најбоље, потврђује могућност употребе експланаторних (објаснидбених) везника као верификатора апозицијског односа (Валгина 2000: 121), у које у руском језику спадају нпр. то eсть., а имено, или, как и др., док су у српском језику најчешћи односно; уп.: брдо Стражевица $\rightarrow$ Стражевица, односно/mј. брдо; село Придворица $\rightarrow$ Придворица, односно/mj. село; манастир Манасија $\rightarrow$ Манасија, mj./односно манастир; тенисер Новак Ђоковић $\rightarrow$ Новак Ђоковић, тј./односно тенисер; отац Анђелко $\rightarrow$ Анђелко, тј./односно отац; учитељ Власта $\rightarrow$ Власта, тј. /односно учитель; кнегиња Милица $\rightarrow$ Милица, тј./односно кнегиња; хотел „Србија” $\rightarrow$ „Србија”, тј./односно хотел; часопис „Нова Зора” $\rightarrow$ „Нова Зора”, тј./односно часопис; мјесеи септембар $\rightarrow$ септембар, mj./односно мјесеи; дрво смрча $\rightarrow$ смрча, тј./односно дрво; птица врабац $\rightarrow$ врабац, тј./односно птица; пси луталице $\rightarrow$ луталице, тј./односно пси и сл.

И да, на крају, у виду закључка, издвојимо најзначајније научне резултате наше анализе.

Наша анализа у много чему ревидира досадашња пре свега србистичка, али и поједина рјешења у другим филологијама. Анализа је, наиме, показала да од тога која се од двију именица сматра надређеним чланом синтагме - зависи и статус саме синтагме - да ли је она атрибутивна или апозицијска. Ако је надређени члан ОДРЕЂЕНИ ПОЈАМ (а то у синтагми са властитом именицом мора бити управо властита именица, а у синтагми са односом именица ширег и ужег појма, мора бити именица за „ужи” појам) - онда је синтагма апозицијска, у којој неодређенији појам, без обзира да ли се налази

\footnotetext{
${ }^{5} \mathrm{O}$ експланаторној (објаснидбеној) синтаксичко-семантичкој категорији, и типовима експланаторних (објаснидбених) везника у српском језику в. исцрпно у Ковачевић (1998: 58-79).
} 
испред или иза одређеног, представља реименовање одређеног појма и има функцију апозиције. Семантички еквивалент апозицијској именици увијек је нерестриктивна релативна реченица, која је истовремено и верификатор апозицијског статуса именице. У апозицијској синтагми именице су у хомофункционалној (независној) синтагматској вези.

Ако је надређени члан синтагме НЕОДРЕЪЕНИ ПОЈАМ (а то су увијек апелативи са значењем ширег појма) - онда је синтагма АТРИБУТИВНА, јер ужи појам (и кад је властито име и кад је заједничка именица) врши функцију атрибут(ив)а. Именице у атрибутивној синтагми подразумијевају хетерофункционалну синтагматску везу, тј. између њих постоји однос зависности (именица за ужи појам има одредбену атрибутивну функцију). Еквивалент атрибут(ив)у увијек је рестриктивна релативна реченица, која је истовремено и верификатор његовог атрибутског одредбеног статуса. Будући да је у подјели атрибута основни морфолошки критеријум (не)конгруенција, укључењем атрибутива у атрибуте сви би се атрибути дијелили у три врсте: а) конгруентни атрибути, б) неконгруентни атрибути и в) полуконгруентни атрибути. Ови посљедњи били би атрибутиви, будући да они од особина конгруенције у свим својим подтиповима нужно подразумијевају само слагање у падежу.

\section{ЛИТЕРАТУРА}

Ајановић 1968: Mustafa Ajanović, Apozicija, Pitanja savremenog književnog jezika, br. 6, Sarajevo, 57-80.

Ахманова 1966: Олга Сергеевна Ахманова, Словарь лингвистических терминов, Москва: „Советская Энциклопедия”.

Бабајцева 2015: Вера Васильевна Бабайцева, Синтаксис русского языка, Москва: Издательство „ФЛИНТА”.

Бабић 1963: Stjepan Babić, Jezik, Zagreb: „Privrednik”.

Барић и др. 1979: Eugenija Barić, Mijo Lončarić, Dragica Malić, Slavko Pavešić, Mirko Peti, Vesna Zečević, Marija Znika, Priručna gramatika hrvatskoga književnog jezika, Zagreb: Školska knjiga.

Белић 1958: Александар Белић, О језичкој природи и језичком развитку: лингвистичка испитивања, књига I, друго издање, Београд: Нолит.

Бојашијев и др. 1999: Тодор Бояджиев, Иван Куцаров, Йордан Пенчев, Съвременен български език, София: Издателска къща «Петър Берон».

Брабец/Храсте/Живковић 1968: Ivan Brabec, Mate Hraste, Sreten Živković, Gramatika hrvatskosrpskoga jezika, VIII, neizmijenjeno izdanje, Zagreb: Školska knjiga.

Валгина 2000: Нина Сергеевна Валгина, Синтаксис современного русского языка, Москва: «Агар».

Властелић 2007: Anastazija Vlastelić, Razmišljanja o apoziciji, Hrvatski sintaktički dani, Osijek, 2007. <https://bib.irb.hr/datoteka/339714.Apozicija.doc> (3. 8. 2018.) 
Драгићевић 2007: Рајна Драгићевић, Лексикологија српског језика, Београд: Завод за уџбенике.

Катичић 1986: Radoslav Katičić, Sintaksa hrvatskoga književnog jezika: Nacrt za gramatiku, Zagreb: JAZU.

Клајн 2005: Ivan Klajn, Gramatika srpskogjezika, Beograd: Zavod za udžbenike i nastavna sredstva.

Ковачевић 1998: Милош Ковачевић, Синтакса сложене реченице у српском језику, Београд: „Рашка школа”, Србиње: СПКД „Просвјета”.

Ковачевић 2015: Милош Ковачевић, Стилистика и граматика стилских фигура, IV битно допуњено издање, Београд: Јасен.

Кордић 1995: Snježana Kordić, Relativna rečenica, Zagreb: Hrvatsko filološko društvo.

Кристал 1988: Dejvid Kristal, Enciklopedijski rečnik moderne lingvistike, Beograd: Nolit.

Маретић 1963: Tomo Maretić, Gramatika hrvatskoga ili srpskoga književnog jezika, III nepromijenjeno izdanje, Zagreb: Matica hrvatska.

Мацановић 2018: Ана Мацановић, Српска језикословна терминологија у 19. веку, Београд: Институт за срски језик САНУ.

Минова Ђуркова 2000: Лилјана Минова-Ѓуркова, Синтакса на македонскиот стандарден јазик, Скопје: МАГОР.

Миновић 1968: Milivoje Minović, Apozicija i apozitivnost, Pitanja savremenog književnog jezika, br. 6, Sarajevo, 81-92.

Мразовић/Вукадиновић 1990: Pavica Mrazović, Zora Vukadinović, Gramatika srpskohrvatskog jezika za strance, Sremski Karlovci: Izdavačka knjižarnica Zorana Stojanovića, Novi Sad: Dobra vest.

Мршевић Радовић 1976: Драгана Мршевић-Радовић, Атрибутиви у српскохрватском језику, Књижевност и језик, ХХІІІ/3, 223-229.

Новаковић 1894: Стојан Новаковић, Српска граматика, Београд: Државна штампарија.

Пецо/Станојчић (ред.) 1972: Enciklopedijski leksikon Mozaik znanja, tom 1: Srpskohrvatski jezik, urednici Asim Peco i Živojin Stanojčić, Beograd: Interpres, 1972.

Пипер/Клајн 2013: Предраг Пипер, Иван Клајн, Нормативна граматика српског језика, Нови Сад: Матица српска.

Регенбоген/Мајер (ред.) 2004: Речник филозофских појмова, приредили Арним Регенбоген и Уве Мајер, Београд: БИГЗ Publishing.

Роговцов 2001: Василь Івановіч Рагаўцоў, Сінтаксіс беларускай $і$ рускай моў: Дыскусійныл пытанні, Мінск: «Университэцкае».

Силић/Прањковић 2005: Josip Silić, Ivo Pranjković, Gramatika hrvatskoga jezika za gimnazije i visoka učilišta, Zagreb: Školska knjiga.

Симеон 1969: Rikard Simeon, Enciklopedijski rječnik lingvističkih naziva, Zagreb: Matica hrvatska.

Симић 1999: Радоје Симић, Основи синтаксе српскога језика I: Теорија исказних форми, Београд: Научно друштво за неговање и проучавање српског језика, Никшић: Јасен. 
Станковић 1986: Богољуб Станковић, Апозиција у српскохрватском и руском језику, Јужнословенски филолог, XLII, 43-65.

Станојчић 2010: Живојин Станојчић, Граматика српског књижевног језика, Београд: Креативни центар.

Станојчић/Поповић 1992: Живојин Станојчић, Љубомир Поповић, Граматика српскога језика. Уибеник за I, II, III и IV разред средње школе, Београд-Нови Сад: Завод за издавање уџбеника и наставна средства.

Стевановић 1958: Михаило Стевановић, Карактер одредаба самосталних речи и разлике међу њима, Јужнословенски филолог, XXIII, 23-34.

Стевановић 1979: Михаило Стевановић, Савремени српскохрватски језик (граматички системи и књижевнојезичка норма) II Синтакса, 3. издање, Београд: Научна књига.

Стевовић 1960: Игрутин Стевовић, Функционална граматика српскохрватског језика, Београд: Завод за издавање уџбеника Народне Републике Србије.

Тополињска 1981: Зузана Тополињска, Рестрикција насупрот апозиције: две врсте атрибута именичке синтагме, Јужнословенски филолог, XXXVII, $1-11$.

Топоришич 2004: Jože Toporišič, Slovenska slovnica, 4. prenovljena in razširjena izdaja, Maribor: Obzorja.

Филиповић (ред.) 1989: Filozofijski rječnik, treće dopunjeno izdanje, redakcija Vladimir Filipović, Zagreb: Nakladni zavod Matice hrvatske.

Хавранек/Једличка 1963: Bohuslav Havránek, Alois Jedlička, Česká mluvnice, Praha: Státní pedagogické nakladateství.

Хлебец 1996: Борис Хлебец, Принципи формирања биноминалних сложеница и синтагми у српском језику, у: О лексичким позајмљеницама (ур. Јудита Планкош), Суботица: Градска библиотека Суботица, Београд: Институт за српски језик САНУ, 140-145.

Шевц-Шустер 1976: Н. Šewc-Schuster, Gramatika hornjoserbskeje rěče, Budyšin: Ludowe nakładnistwo Domowina.

Miloš M. Kovačević

\section{THE STATUS OF ATTRIBUTIVE AMONG DETERMINERS IN THE SLOVENIAN LANGUAGES}

Summary

This paper analyses grammatical and scientific interpretations of nominal syntagms, which are composed of syntactic-semantic units that only the Serbian literature calls attributive.

Syntagms consisting of two nouns, one of which is broader and the other is narrower, and which are commonly realised as syntagms consisting of a prepositive common noun and proper noun - are subsumed under the attributive syntagms in the grammatical and scientific Serbian literature, which considers that the noun for the broader term has the status of a dependent member which is terminologically defined only in the Serbian literature as an attributive. In almost all Slovenian philologies all 
these syntagms are defined as apposition, but there is no unique opinion regarding the definition of the main and subordinate member of the syntagm.

Our analysis, in many ways, revises previous, primarily Serbian solutions, as well as those from other philologies. Namely, the analysis has shown that the status of the syntagm - whether it is attributive or apposition - depends on which of the two nouns is considered to be the main member of the syntagm. If the main member is a definite term (in the syntagm with a proper noun it must be a proper noun, and in the syntagm with the relation of a wider and narrower term, it must be a noun for the narrower "term") - then the syntagm is apposition, in which an indefinite term, regardless of whether it is in front of or behind a definite, represents renaming of a definite term and has the function of apposition. Equivalent of the appositive noun is always a non-restrictive relative sentence, which is at the same time a verifier of the appositive status of a noun. In the appositive syntagm, the nouns are in a homofunctional (independent) syntagmatic relation.

If the main member of the syntagm is an indefinite term (and they are always appellative with the meaning of a wider term), then the syntagm is attributive, because the narrower term (both proper and common noun) performs the function of attribut(iv)e. Nouns in the attributive syntagm include heterofunctional syntagmatic relation, i.e. there is a relation of dependence between them (the noun for the narrower term always has defining attributive function). Equivalent of the attribut(iv)e is always a restrictive relative sentence, which is at the same time a verifier of its attributive defining status.

Key words: attribute, apposition, attributive, main member of syntagm, definite term, wider term, narrower term. 